\title{
Association of Serum PSA Levels with Histopathological Pattern of Prostate Lesions
}

\author{
Afra Samad 1, Nudrat Fayyaz 2, Ayesha Siddiqa ${ }^{3}$, Naseem Akhter ${ }^{4}$, Rabia Saeed 5, Maryam Rafiq ${ }^{6}$, Aqsa Ashraf \\ Bukhari ${ }^{7}$, Ayesha Afzal ${ }^{8}$ \\ ${ }^{1}$ Associate Professor, Department of Pathology, Multan Medical \& Dental College, Multan \\ ${ }^{2}$ Assistant Professor, Department of Chemical pathology, Multan Medical and Dental College Multan \\ ${ }^{3}$ Consultant Pathologist, District Health Authority, T.H.Q. Hospital, Yazman, Bahawalpur \\ ${ }^{4}$ Assistant Professor, Department of Hematology, Ibn-e-Sina hospital, Multan \\ ${ }^{5}$ Assistant Professor., Department of Chemical Pathology, Combined Military Hospital, Bahawalpur \\ ${ }^{6}$ Assistant Professor. Department of Chemical Pathology, Sahiwal Medical College, Sahiwal \\ ${ }^{7}$ Microbiologist, Multan Medical and Dental College, Multan \\ ${ }^{8}$ PhD Scholar Human Genetics and Molecular Biology \& Lecturer, GC University, Faisalabad
}

\section{A B STRACT}

\begin{abstract}
Background: Pathological changes that mainly affect prostate gland are prostatitis, benign prostatic hyperplasia (BPH) and cancerous lesions. Digital rectal examination (DRE), Transrectal Ultrasonography (TUS), and prostate specific antigen (PSA) followed by histopathological examination, are routinely used tests for diagnosis of prostate lesions. The aim of the present study is to determine the role of serum PSA levels in differentially diagnosing the different types of prostate lesions.

Material and Methods: This retrospective (observational) study was conducted in Ibn-e-Sina Hospital Multan. Data of 2189 patients who were operated from 2007 to 2017 due to prostatic lesions were included in this analysis. Patients with BPH, prostatitis, prostate carcinoma and Prostatic Intraepithelial Neoplasia (PIN) were grouped according to serum PSA levels (ranging from 0 to $>100 \mathrm{ng} / \mathrm{ml}$ ) into five groups. Frequencies and percentages were calculated for different histopathological findings. Association of PSA levels with different histological patterns was determined with chi-square test with P-value $<0.05$ taken as significant difference.

Results: Mean age of patients was $62.45+10.64$ years. On histopathology, BPH was diagnosed in $1676(76.56 \%)$ patients, prostatitis in $133(6.07 \%)$, carcinoma in $378(17.26 \%)$ and PIN in $02(0.09 \%)$ patients, respectively. Serum PSA levels of 4.01-10 $\mathrm{ng} / \mathrm{ml}$ were found in 1050 (62.64\%) BPH patients and in $59(44.36 \%)$ prostatitis patients. Serum PSA levels of $10.01-20 \mathrm{ng} / \mathrm{ml}$ were found in only $40(2.4 \%) \mathrm{BPH}$ patients, 47 (35.33\%) prostatitis patients, $22(5.82 \%)$ carcinoma patients and in $1(50.0 \%)$ PIN patient. Serum PSA levels of $20.01-100 \mathrm{ng} / \mathrm{ml}$ were found in $32(1.9 \%) \mathrm{BPH}$ patients, $11(8.27 \%)$ prostatitis patients, $302(79.89 \%)$ carcinoma patients, and in $1(50.0 \%)$ PIN patient. Serum PSA levels of $>100 \mathrm{ng} / \mathrm{ml}$ were absent in patients with BPH and PIN, and present in $1(0.75 \%)$ prostatitis and $54(14.28 \%)$ carcinoma patients.
\end{abstract}

Conclusion: Benign prostatic hyperplasia was the commonest lesion in our patients $(76.56 \%)$ with serum PSA levels $>10 \mathrm{ng} / \mathrm{ml}$ reported in all patients with prostate carcinoma and prostatic intraepithelial neoplasia (PIN) patients.

Key words: Benign prostatic hyperplasia, Prostate carcinoma, Prostate specific antigen, Prostatic intraepithelial neoplasia, Prostatitis

Authors' Contribution:

${ }_{1,2}$ Conception, synthesis, planning of research and manuscript writing ${ }^{3,4}$ Interpretation, ${ }^{5-8}$ discussion, Active participation in data collection Data analysis.

Cite this article. Samad A, Fayyaz N, Siddiqa S, Akhter N, Saeed R, Rafiq M, Bukhari AA, Afzal A. Association of serum PSA levels with Histopathological Pattern of Prostate Lesions. J Islamabad Med Dental Coll.2019; 8(2):92-95
Correspondence: $\quad$ Article info:

Nudrat Fayyaz

Email: nudrat_khan_07@yahoo.com
Received: January 4, 2019

Accepted: April 10, 2019
Funding Source: Nil

Conflict of Interest: Nil 


\section{Introduction}

Benign prostatic hyperplasia (BPH), prostatitis and carcinoma are three most common prostate lesions with $\mathrm{BPH}$ as the commonest lesion, affecting 210 million of the male population worldwide. ${ }^{1} \mathrm{BPH}$ is now considered a normal part of aging as it is present in $100 \%$ male population of age $>80$ years. ${ }^{1}$ Cancer of prostate is ranked as the second most common cancer and fifth leading cause of death due to cancer in males. ${ }^{2}$

Pathological changes that mainly affect prostate gland are prostatitis, benign prostatic hyperplasia (BPH), PIN and prostate cancer. There is an increasing incidence of prostate cancer and BPH with increasing age, however $\mathrm{BPH}$ is reported as the commonest lesion. ${ }^{3}$ Histological findings of $\mathrm{BPH}$ are present in $20 \%$ of males at the age of 40 years, in $70 \%$ at 60 years and in $90 \%$ by the time they reach 80 years of age. ${ }^{3}$ Peak incidence is reported in the sixth decade of life in the Pakistani population. ${ }^{4}$ While in some other countries the peak incidence is in the ninth decade of life..$^{5}$ In addition to age, other risk factors of prostate lesions are those concerned with metabolic disorders such as diabetes, obesity, dyslipidemia and physical inactivity. ${ }^{4}$

Digital rectal examination (DRE), Transrectal Ultrasonography, and prostate specific antigen (PSA) followed by histopathological examination are routinely used tests for the diagnosis of prostate lesions. ${ }^{6}$ PSA is physiologically secreted in semen in high concentrations for liquefication of semen coagulum. ${ }^{7}$ PSA is also found in human blood plasma/serum and is widely used for detection of prostate pathology since 1988. PSA levels increase in proportion with disease severity and studies have found that a steep increase in PSA level increases the likelihood of diagnosis of prostate cancer. 8,9

Serum PSA levels $<4.0 \mathrm{ng} / \mathrm{ml}$ in patients with prostate lesions are considered normal, $4-10 \mathrm{ng} / \mathrm{ml}$ are border line while $>10 \mathrm{ng} / \mathrm{ml}$ are considered to have a high risk for malignancy. PSA levels are only used to diagnose lesions and histopathological examination is needed to differentiate different types of lesions.
The aim of the present study was to determine the role of serum PSA levels in differentially diagnosing the different histopathological types of prostate lesions.

\section{Material and Methods}

This retrospective study was conducted in Ibn-e-Sina Hospital Multan. Data of 2189 patients who were operated from 2007 to 2017 due to prostatic lesions were included in this analysis. Patients with inadequate biopsy specimens were excluded. Departmental and ERB approval was taken before analyzing the data. Patients with $\mathrm{BPH}$, prostatitis, prostate carcinoma and prostatic intraepithelial neoplasia (PIN) were grouped according to serum PSA levels (ranging from 0 - >100 ng/ml) into five groups Serum PSA levels done before surgery were noted for each patient. Biopsy specimens were brought to the histopathology laboratory in $10 \%$ formalin solution for confirmation of the diagnosis of prostate lesions. These sections were then stained with eosin and hematoxylin stain and slides were evaluated microscopically for determination of types of lesions. Consultant histopathologist made the final diagnosis of prostate lesions.

All the data was entered in SPSS version 21. Frequencies and percentages were calculated for different histopathological findings. Association of serum PSA levels with different histopathological patterns was determined using chi-square test with P-value $<0.05$ taken as a significant difference

\section{Results}

Mean age of all patients was $62.45 \pm 10.64$ years. On histopathology, BPH was diagnosed in 1676 (76.56\%) patients, prostatitis in $133(6.07 \%)$, carcinoma in 378 $(17.26 \%)$ and PIN in $02(0.09 \%)$ patients only (Table I). On comparison of serum PSA levels with various types of histopathological lesions, almost all patients of BPH, and about $55 \%$ patients of prostatitis had PSA levels within the range of $0-10 \mathrm{ng} / \mathrm{ml}$. 


\begin{tabular}{|l|c|c|}
\hline \multicolumn{3}{|c|}{ Table I. Frequency Distribution of Histopathological Lesions } \\
\hline \multicolumn{1}{|c|}{ Type of Lesion } & $\begin{array}{c}\text { Frequency } \\
\text { (n) }\end{array}$ & $\begin{array}{c}\text { Percentage } \\
(\%)\end{array}$ \\
\hline BPH & 1676 & 76.56 \\
\hline Prostatitis & 133 & 6.07 \\
\hline Acute Prostatitis & 26 & 1.18 \\
\hline Chronic Prostatitis & 83 & 3.79 \\
\hline Acute and Chronic Prostatitis & 24 & 1.09 \\
\hline Carcinoma & 378 & 17.26 \\
\hline Adenocarcinoma & 364 & 16.62 \\
\hline Transitional cell carcinoma & 01 & 0.045 \\
\hline Mucinous Adenocarcinoma & 02 & 0.09 \\
\hline Adenoid basaloid tumor & 01 & 0.045 \\
\hline Rhabdomyosarioma & 01 & 0.045 \\
\hline Small cell tumor & 01 & 0.045 \\
\hline Squamous cell carcinoma & 03 & 0.14 \\
\hline Infiltration by TCC & 02 & 0.09 \\
\hline Large cell type & 01 & 0.045 \\
\hline Sarcomatoid varices & 01 & 0.045 \\
\hline Leiomyoma & 01 & 0.045 \\
\hline PIN & 02 & 0.09 \\
\hline Total & 2189 & 100 \\
\hline
\end{tabular}

About $50 \%$ patients of PIN had PSA levels in the range of 10-20 ng/ml, while more than $90 \%$ patients of prostate cancer had PSA levels $>20 \mathrm{ng} / \mathrm{ml}$ (Table II).
In our study, BPH was diagnosed in 1676 (76.56\%) patients, prostatitis in $133(6.07 \%)$, Carcinoma in 378 $(17.26 \%)$ and PIN in $02(0.09 \%)$ patients only. Patel and Surti reported $\mathrm{BPH}$ in $68.75 \%$ patients, followed by carcinoma in $25 \%$ cases and prostatitis in only $1.8 \%$ patients. ${ }^{14}$ Shetty et al. reported BPH in only $36.6 \%$ patients, prostatitis in $30 \%$, PIN in $15.3 \%$ and carcinoma in $18 \%$ patients. ${ }^{15}$ Gurumurthy et al. reported PIN in $5.95 \%$ cases of prostatic lesions. ${ }^{16}$ Horninger et al. reported frequency of PIN in $2.91 \%$ patients and Anderson-Jackson et al. in $4.07 \%$ patients, respectively. 17,18 All these studies report contrasting results, which are much different from our study.

Serum PSA is the most widely used tumor marker but it cannot be used alone because it has low sensitivity and specificity, especially when the PSA levels are low. Elevation of PSA level occur in conditions such as BPH, prostatitis, prostatic infarct and especially in carcinoma of prostate. In the present study, we correlated the serum PSA levels with histopathological diagnosis of prostate lesions. We found significant association of PSA with

\begin{tabular}{|c|c|c|c|c|c|}
\hline \multicolumn{6}{|c|}{ Table II. Association of Serum PSA Levels with common types of Histopathological Lesions } \\
\hline PSA (ng/ml) & $\begin{array}{c}\mathrm{BPH} \\
(n=1676)\end{array}$ & $\begin{array}{c}\text { Prostatitis } \\
(n=133)\end{array}$ & $\begin{array}{c}\text { Carcinoma } \\
(n=378)\end{array}$ & $\begin{array}{c}P I N \\
(n=02)\end{array}$ & P-Value \\
\hline $0-4.0$ & $554(33.05 \%)$ & $15(11.27 \%)$ & $0(0.0 \%)$ & $0(0.0 \%)$ & \multirow{5}{*}{$<0.05$} \\
\hline $4.01-10$ & $1050(62.64 \%)$ & $59(44.36 \%)$ & $0(0.0 \%)$ & $0(0.0 \%)$ & \\
\hline $10.01-20$ & $40(2.4 \%)$ & $47(35.33 \%)$ & $22(5.82 \%)$ & $1(50.0 \%)$ & \\
\hline $20.01-100$ & $32(1.9 \%)$ & $11(8.27 \%)$ & $302(79.89 \%)$ & $1(50.0 \%)$ & \\
\hline$>100$ & $0(0.0 \%)$ & $1(0.75 \%)$ & $54(14.28 \%)$ & $0(0.0 \%)$ & \\
\hline
\end{tabular}

\section{Discussion}

$\mathrm{BPH}$ and prostate carcinoma are very common in males especially in geriatric age and results in lower urinary tract symptoms. PSA levels, DRE, and transurethral USG and biopsy investigations are routinely used tests for diagnosing prostate lesions. ${ }^{10}$ Mean age of all patients in the present study was $62.45 \pm 10.6$ years. This is in agreement with the mean age reported by multiple studies including Khant et al. $(66.9 \pm 9.4$ years $),{ }^{10}$ Josephine (65.5 years), ${ }^{11}$ and Lakhey et al. (67.6 years) ${ }^{12}$ in Indian and Nepalese patients respectively. In comparison, Jasani and colleagues reported mean age of $57.77 \pm 4.86$ years for patients with $\mathrm{BPH}$ and $65.82 \pm 5.6$ years for patients with prostate cancer. ${ }^{13}$ carcinoma of prostate; PSA levels were $>10 \mathrm{ng} / \mathrm{ml}$ in all patients with prostate carcinoma and PIN. In our study, PSA levels $<10.0 \mathrm{ng} / \mathrm{ml}$ were found in $76.65 \%$ of the patients. Murthy et al. reported normal PSA levels in more than $40 \%$ patients who underwent prostate biopsy. ${ }^{19}$ Another study by El-imam et al. reported PSA $>4$ to $<10.0$ $\mathrm{ng} / \mathrm{ml}$ in $>70 \%$ of Sudanese patients. ${ }^{20}$ Wadgaonkar et al. and Gurumurthy et al. reported findings similar to our study with significant elevation in serum PSA levels in PIN and prostate carcinoma patients. ${ }^{21,16}$

Serum PSA levels more than $10 \mathrm{ng} / \mathrm{ml}$ is highly indicative of prostate cancer. So, patients having PSA $>10 \mathrm{ng} / \mathrm{ml}$ should be considered for surgical intervention as early as possible because of high probability of prostate carcinoma. The limitation of the present study is that we 
did not correlate the severity/grades of prostate cancer (Gleason scores) with serum PSA levels.

\section{Conclusion}

In our study, benign prostatic hyperplasia was the commonest prostate lesion $(76.56 \%$ of the patients) and serum PSA levels of $>10 \mathrm{ng} / \mathrm{ml}$ was found in all patients with prostate carcinoma and prostatic intraepithelial neoplasia (PIN).

\section{References}

1. Arya RC, Minj MK, Tiwari AK et al. Pattern of Prostatic Lesions in Chhattisgarh Institute of Medical Sciences, Bilaspur: A Retrospective Tertiary Hospital Based Study. Int J Scientific Study 2015;3(6):179-82.

2. Bray F, Ferlay J, Soerjomataram I, Siegel RL, Torre LA, Jemal A. Global cancer statistics 2018: GLOBOCAN estimates of incidence and mortality worldwide for 36 cancers in 185 countries. CA: Cancer J Clin. 2018; 68: 394424. doi: 10.3322/caac.21492.

3. Kumar V, Abbas AK, Fausto N, Aster JC. Robbins and Cotran pathologic basis of disease. Philadelphia: Elsevier Saunders; 2005; $8: 208-21$

4. Aslam HM, Shahid N, Shaikh NA, Shaikh HA, Saleem S, Mughal A. Spectrum of prostatic lesions. Int Arch Medicine. 2013; 6(1): 36. doi: 10.1186/1755-7682-6-36

5. Ojewola RW, Oridota ES, Balogun OS, Alabi TO, Ajayi Al, Olajide TA, et al. Prevalence of clinical benign prostatic hyperplasia amongst community-dwelling men in a SouthWestern Nigerian rural setting: A cross-sectional study. Afr J Urol. 2017;23(2):109-15. doi: 10.1016/j.afju.2016.02.004

6. Heidenreich A, Bellmunt J, Bolla M, Joniau S, Mason M, Matveev $\mathrm{V}$, et al. EAU guidelines on prostate cancer.Part 1: screening, diagnosis, and treatment of clinically localised disease. Eur Urol. 2011; 59(1): 61-71. doi: 10.1016/j.eururo.2010.10.039

7. Lee C, KEEFER M, ZHAO ZW, KROES R, BERG L, LIU X, SENSIBAR J. Demonstration of the role of prostate-specific antigen in semen liquefaction by two-dimensional electrophoresis. Journal of andrology. 1989 Nov 12;10(6):432-8.

8. Brawer MK, Chetner MP, Beatie J, Buchner DM, Vessella $\mathrm{RL}$, Lange $\mathrm{PH}$. Screening for prostatic carcinoma with prostate specific antigen. J Urol. 1992; 147(3 Part 2): 841-5. doi: 10.1016/s0022-5347(17)37401-3

9. Gretzer MB, Partin AW. PSA levels and the probability of prostate cancer on biopsy. Eur Urol Suppl. 2002; 1(6): 21-7. doi: 10.1016/S1569-9056(02)00053-2.

10. Khant VS, Goswami H, Shah PY. Correlation of serum prostate-specific antigen level in various prostate pathology in elderly men. International J Med Sci Public Health. 2017; 6(2): 257-62. doi: 10.5455/ijmsph.2017.17072016588

11. Josephine A. Clinicopathological study of prostatic biopsies. J Clin Diagn Res. 2014; 8(9): FC04-06. doi: 10.7860/JCDR/2014/8591

12. Lakhey M, Ghimire R, Shrestha R, Bhatta A. Correlation of serum free prostate-specific antigen level with histological findings in patients with prostatic disease. Kathmandu Uni Med J. 2010; 8(30): 158-63. PMID: 21209527

13. Jasani JH, Patel HB, Gheewala B, Vaishnani HV, Bhuva K. Diagnostic utility of prostate specific antigen for detection of prostatic lesions. Int J Biomed Adv Res. 2012; 3(4): 26872. DOI: 10.7439/ijbar.V3i4.425.

14. Patel SK, Surti HB. Analysis of prostatic biopsies in a tertiary care hospital in correlation with prostate-specific antigen levels: A clinicopathological study. Int J Med Sci Public Health. 2017; 6(5): 842-6. doi: 10.5455/ijmsph.2017.1266106122016

15. Shetty PP, Singh BM, Shetty T, Bishnu A. Correlation of prostate specific antigen level with histopathological findings in patients with prostatic disease. Trop J Pathol Microbiol. 2016; 2(3): 152-8

16. Gurumurthy D, Maggad R, Patel S. Prostate carcinoma: Correlation of histopathology with serum prostate specific antigen. Int J Sci Technol Soc. 2015; 4: 1-5. doi: 10.11648/j.sjcm.s.2015040401.11

17. Horninger $W$, Volgger $H$, Rogatsch $H$, Strohmeyer $D$, Steiner $\mathrm{H}$, Hobisch $\mathrm{A}$, et al. Predictive value of total and percent free prostate specific antigen in high grade prostatic intraepithelial neoplasia lesions: results of the Tyrol Prostate Specific Antigen Screening Project. J Urol. 2001; 165(4): 1143-5. doi: 10.1016/S0022-5347(05)66451-8.

18. Anderson-Jackson L, McGrowder DA, Alexander-Lindo R. Prostate specific antigen and Gleason score in men with prostate cancer at a private diagnostic radiology centre in Western Jamaica. Asian Pacific J Cancer Prev. 2012; 13(4): 1453-6. doi: 10.7314/apjcp.2012.13.4.1453

19. Murthy D, Ray U, Morewaya J, SenGupta S. A study of the correlation of prostatic pathology and serum prostatespecific antigen (PSA) levels: a perspective from Papua New Guinea. Papua N Guinea Med J. 1998; 41(2): 59-64.

20. Mohammed El Imam MA, Higazi NZ, Abuidris DO, Idris AA, Khalid KE, Omran M, et al. Prostate Specific Antigen versus Digital Rectal Examination as screening for ca prostate in Sudanese patients. Sudan J Public Health. 2009; 4(2): 27881.

21. Wadgaonkar A, Patil A, Mahajan S, Yengantiwar R. Correlation of serum prostate specific antigen (PSA) level in various prostate pathology in elderly men. Int $\mathrm{J}$ Basic Applied Med Sci. 2013; 3(2): 274-8. 